\title{
Tree Growth Management and Fruit Quality of Apple Trees Treated with Prohexadione-calcium (BAS 125)
}

\author{
Duane W. Greene \\ Department of Plant and Soil Sciences, University of Massachusetts, Amherst, MA 01003-0910
}

\begin{abstract}
A delicate balance exists between vegetative growth and cropping in apple trees. Frequently, management mistakes or abnormal weather conditions disrupt this balance, resulting in excessive vegetative growth. Vigorous growth can negatively influence fruit quality, productivity, pest control, and profit (Forshey et al., 1992).

A number of growth control techniques are available (Greene and Autio, 1994), but all have faults. Ethephon can control tree growth, but thins fruit if applied at the time and concentrations that most effectively control growth, stimulates preharvest drop, and advances ripening (Autio and Greene, 1994). Root pruning is effective but reduces fruit size and potentially causes trees to be less firmly anchored (Schupp and Ferree, 1988). Aggressive pruning will reduce tree size initially, but pruned trees ultimately will grow even more vigorously, resulting in reduced flower bud formation and fruit set and lower fruit quality and yield (Alderman and Auchter, 1916; Pearson, 1895).

Young leaves and growing points are rich sources of gibberellins (Jones and Phillips, 1966). Rapidly growing shoots produce large amounts of gibberellins that presumably diffuse down the stem and inhibit flower bud formation. Because gibberellins are mobile, one can speculate that those produced in shoot tips can inhibit flowering long distances from their site of synthesis (Cleland, 1969). Vigorous trees usually produce more shoots, resulting in excessive shading on the interior of a tree. Flower bud formation does not occur in apple buds exposed to light levels below $30 \%$ full sun, and weak flower buds are formed at light levels slightly above this (Cain, 1971). Consequently,
\end{abstract}

Received for publication 17 Nov. 1998. Accepted for publication 18 Nov. 1998. The cost of publishing this paper was defrayed in part by the payment of page charges. Under postal regulations, this paper therefore must be hereby marked advertisement solely to indicate this fact. flowering in vigorous trees is frequently reduced because light levels inside the tree canopy are below the critical level. Large areas in the tree's interior may be devoid of flowers, leaving only a thin mantel of fruiting wood on the exterior.

Fruit quality on trees with excessive vegetative growth is frequently poor, and the storage potential of these fruit is generally diminished (Forshey et al., 1992). Shading due to excessive vegetative growth indirectly affects fruit quality. Shading reduces red color, and if red color is reduced to a level where grade is lowered, production costs may actually exceed income from the sale of the fruit (Autio and Greene, 1990).

Pruning is one of the most expensive and time-consuming management activities (Felland, 1998), especially with vigorous trees. Reducing tree growth reduces pruning costs (Forshey et al., 1992).

High rates of gibberellin biosynthesis stimulate excessive vegetative growth. Inhibitors of gibberellin biosynthesis retard growth and improve plant productivity and/or performance (Rademacher, 1991). Paclobutrazol, a gibberellin biosynthesis inhibitor, was used successfully on fruit trees to control growth and improve fruit quality, although it is not commercially available in the United States for this purpose (Elfving and Proctor, 1986; Greene, 1991). Cyclohexanetriones are a new class of gibberellin biosynthesis inhibitors (Rademacher et al., 1992). Of these, prohexidione-calcium appears to be particularly effective, and has potential for improving performance (Rademacher, 1991). The purpose of this investigation was to determine the optimum concentrations and time(s) of application of prohexadione-calcium (Apogee $^{\circledR}$, BAS 125) for controlling vegetative growth of apple trees, as well as the effects of BAS 125 on fruit quality, fruit set, and return bloom. 


\section{MATERIALS AND METHODS}

Expt. 1. McIntosh. Thirty mature 'McIntosh'/M.7 apple trees were selected at the Univ. of Massachusetts, Horticultural Research Center, Belchertown. Two limbs 10 to $15 \mathrm{~cm}$ in diameter on each tree were tagged prior to bloom and all blossom clusters counted on each tagged limb at the pink stage of flower development. Trees were blocked into six groups (replications) of five trees each based upon blossom cluster density. On 31 May when shoot length was 12 to $13 \mathrm{~cm}$ and fruit diameter averaged $9.5 \mathrm{~mm}$, one tree in each block was sprayed with BAS 125 10W $\left(125,250\right.$, or $375 \mathrm{mg} \cdot \mathrm{L}^{-1}$ in $0.1 \%$ Triton B 1956$)$ at $1 \mathrm{X}$ using a hand gun. One tree in each block was left unsprayed and served as the control. All trees in the block were thinned with NAA $\left(3 \mathrm{mg} \cdot \mathrm{L}^{-1}\right)$ combined with carbaryl $\left(600 \mathrm{mg} \cdot \mathrm{L}^{-1}\right) 7 \mathrm{~d}$ after BAS 125 application. Ten shoots per tree were tagged and measured just before spray application and periodically throughout the growing season. At the end of the "June" drop period in July, all persisting fruit on tagged limbs were counted. The remaining tree in each block was summer pruned in August according to industry standards. A 30-fruit sample was harvested randomly from the periphery of each tree at the normal harvest time. Fruit were weighed and the percentage of red surface color was estimated visually to the nearest $10 \%$. In addition, the color intensity was rated as typical or atypical of 'McIntosh'. A representative 10-fruit subsample was selected and flesh firmness was determined based upon two punctures per fruit using an Efegi penetrometer equipped with an 11-mm-diameter head. Soluble solids was determined with a hand-held refractometer using the juice collected during the pressure test. Starch index was rated using the method of Priest and Lougheed (1988). The remaining 20 fruit in each sample were cut and the number of viable seeds counted. Total yield per tree was determined by harvesting and weighing the remaining fruit on each tree and combining that with the weight of fruit on the ground.

A 20-kg fruit sample was taken at harvest and placed in regular air storage at $0{ }^{\circ} \mathrm{C}$ for 20 weeks. Fruit were removed and flesh firmness was determined on a 20-fruit sample. The remaining fruit were allowed to remain at room temperature for 2 weeks, then all fruit were evaluated for storage disorders. The time required to prune each tree was recorded during the dormant period. Return bloom the following year was determined by counting all blossom clusters on two tagged limbs per tree.

Expt. 2. 'Macoun'. From a block of mature 'Macoun'/M.7 trees in a commercial orchard in Belchertown, Mass., 42 trees were selected. At least one buffer tree was left between each treatment tree. Prior to bloom two limbs per tree were tagged and the number of blossom clusters were counted at the pink stage of blossom development. Trees were blocked into seven groups of six trees each based upon bloom density. Within each block, treatments were assigned randomly. On 28 May when shoot growth was $\approx 5 \mathrm{~cm}$, petal fall $(\mathrm{PF})$ treatments were applied with a tractor-mounted speed sprayer at the tree-row-volume of $1870 \mathrm{~L} \cdot \mathrm{ha}^{-1}$. All solutions contained $0.1 \%$ Regulaid as a wetting agent. One tree was sprayed with $\approx 5.5 \mathrm{~L}$ of BAS 125 at 30,60 , or 270 $\mathrm{mg} \cdot \mathrm{L}^{-1}$, while two trees received a spray of $90 \mathrm{mg} \cdot \mathrm{L}^{-1}$. One unsprayed tree in each block served as a control. At the 10-mm stage of fruit development on 12 June all trees in each block were sprayed with NAA $\left(10 \mathrm{mg} \cdot \mathrm{L}^{-1}\right)$ plus carbaryl $\left(900 \mathrm{mg} \cdot \mathrm{L}^{-1}\right)$. Two and 4 weeks after PF trees receiving 30,60 , and one tree receiving $90 \mathrm{mg} \cdot \mathrm{L}^{-1}$ BAS 125 were retreated with the same concentrations. Also, 4 weeks after PF one of the trees that received $90 \mathrm{mg} \cdot \mathrm{L}^{-1}$ at $\mathrm{PF}$ was retreated with $180 \mathrm{mg} \cdot \mathrm{L}^{-1}$ BAS 125.

On 28 May and at weekly intervals, the length of 10 terminal shoots per tree was recorded. Biweekly measurements were taken starting on 1 July and ending on 30 Oct. Forty fruit were randomly selected around the periphery of each tree at the normal harvest date, on 30 Sept. All fruit were weighed and red color estimated to the nearest 10\%. A 10apple sample was taken as described in Expt. 1. Pruning time and return bloom were determined as previously described.

\section{RESULTS}

Expt. 1. 'McIntosh'. The treatments had reduced terminal growth when shoots were measured 2 weeks after application and thereafter
(Table 1). The lowest concentration $\left(125 \mathrm{mg} \cdot \mathrm{L}^{-1}\right)$ was as effective as the higher concentrations. Once growth was stopped by BAS 125 , no regrowth occurred.

Fruit set increased linearly with increasing BAS 125 concentration (Table 2$)$, the highest rate $\left(375 \mathrm{mg} \cdot \mathrm{L}^{-1}\right)$ nearly doubling final fruit set. Fruit size decreased linearly with increasing concentration of BAS 125. Summer pruning did not influence fruit size, and total yield was not influenced by any treatment. Return bloom declined quadratically with increasing dosage of BAS 125 and appeared to be inversely related to fruit set the previous year. Treated trees required less time to prune and this response was linear. Summer-pruned trees also required less time to prune during the dormant season than did the control trees, but considerable time had been spent pruning these trees during the previous summer.

Apples treated with BAS 125 were firmer and had lower soluble solids and a higher starch rating when evaluated at harvest (Table 3 ). Red color was increased substantially by both BAS 125 and summer pruning. This increase resulted in a high percentage of the fruit being graded into the U.S. Extra Fancy category. No treatment affected the number of viable seeds per fruit at harvest (data not shown).

Fruit treated with BAS 125 and stored in regular air storage were firmer than nontreated fruit after 20 weeks of storage (Table 3). Treatment with BAS 125 linearly reduced the amount of decay but increased the incidence of scald appearing after $14 \mathrm{~d}$ at room temperature. Senescent breakdown was very low in fruit in this experiment and no treatment affected this storage disorder (data not shown).

Expt. 2. 'Macoun'. The highest rate of BAS $125\left(270 \mathrm{mg} \cdot \mathrm{L}^{-1}\right)$ had significantly reduced terminal growth 2 weeks after application (Table 4). An additional $6 \mathrm{~d}$ were required after the second application to significantly slow terminal growth on trees receiving lower BAS 125 concentrations. For the duration of the growing season, growth on BAS 125-treated trees remained suppressed, with little additional terminal growth.

Treatment with BAS 125 had little or no influence on fruit weight at harvest when the initial application at PF was $90 \mathrm{mg} \cdot \mathrm{L}^{-1}$ or less, but $270 \mathrm{mg} \cdot \mathrm{L}^{-1}$ at PF significantly reduced size. In general, fruit on trees treated with BAS 125 was more highly colored and more were graded into the U.S. Extra Fancy category. No treatment influenced flesh firmness or soluble solids at harvest. The time required to prune trees decreased linearly with increasing dosage of BAS 125.

\section{DISCUSSION}

Dormant pruning is one of the major production costs in apple production (Felland, 1998). Treatment with BAS 125 reduced the amount of time required to dormant prune trees by more than $30 \%$ in both experiments. This is significant because skilled pruners are becoming increasingly difficult to find. Therefore, reduced vegetative growth would not only lower management costs significantly, but would also require hiring fewer pruners.

'McIntosh' is the dominant apple cultivar grown in New England. Preharvest drop is usually a problem and is frequently severe (Greene et al., 1987). Growers are compelled for economic reasons to wait until fruit develop 50\% red color before harvesting, so that they can be sold as U.S. Extra Fancy. Often preharvest drop intensifies before fruit become this red. Summer pruning has been adopted by many growers to improve color and increase the number of fruit classified as U.S. Extra Fancy (Autio and Greene, 1990). However, summer pruning is expensive and labor intensive, and requires skilled pruners. Summer

Table 1. Effect of concentration of BAS 125 on terminal growth of 'McIntosh' apple trees. Treatments applied 31 May.

\begin{tabular}{lccccccc}
\hline \hline BAS 125 & \multicolumn{7}{c}{ Terminal growth $(\mathrm{cm})$} \\
\cline { 2 - 8 }$\left(\mathrm{mg} \cdot \mathrm{L}^{-1}\right)$ & 31 May & 14 June & 28 June & 14 July & 27 July & 9 Aug. & 10 Nov. \\
\hline 0 & 13.1 & 23.7 & 27.2 & 30.5 & 33.3 & 34.4 & 35.4 \\
125 & 12.6 & 18.5 & 19.4 & 20.0 & 20.5 & 20.5 & 21.0 \\
250 & 13.1 & 18.6 & 19.6 & 20.0 & 20.5 & 20.4 & 21.1 \\
375 & 12.6 & 19.4 & 20.3 & 20.6 & 21.0 & 21.4 & 22.0 \\
Significance & NS & $\mathrm{L}^{* *}, \mathrm{Q}^{* *}$ & $\mathrm{~L}^{* *}, \mathrm{Q}^{* *}$ & $\mathrm{~L}^{* *}, \mathrm{Q}^{* * *}$ & $\mathrm{~L}^{* * *}, \mathrm{Q}^{* *}$ & $\mathrm{~L}^{* * *}, \mathrm{Q}^{* *}$ & $\mathrm{~L}^{* * *}, \mathrm{Q}^{* * * *}$ \\
\hline ss,**,**** Nonsignificant or significant at $P \leq 0.01$ or 0.001, respectively. L $=$ linear; \\
Q = quadratic.
\end{tabular}


Table 2. Effects of concentration of BAS 125 and summer pruning on fruit set, fruit size, yield, pruning time, and return bloom of 'McIntosh' apple trees. Treatments applied 31 May.

\begin{tabular}{|c|c|c|c|c|c|c|}
\hline \multirow[b]{2}{*}{$\begin{array}{l}\text { BAS } 125 \\
\left(\mathrm{mg} \cdot \mathrm{L}^{-1}\right)\end{array}$} & \multicolumn{2}{|c|}{ Fruit per } & \multirow[b]{2}{*}{$\begin{array}{l}\text { Fruit wt } \\
\quad(\mathrm{g})\end{array}$} & \multirow{2}{*}{$\begin{array}{c}\text { Total } \\
\text { yield } \\
\text { (kg/tree) }\end{array}$} & \multirow{2}{*}{$\begin{array}{c}\text { Return bloom } \\
\text { (blossom clusters } \\
\text { per } \mathrm{cm}^{2} \text { limb } \\
\text { x-sectional area) }\end{array}$} & \multirow{2}{*}{$\begin{array}{c}\text { Pruning } \\
\text { time } \\
\text { (min/tree) }\end{array}$} \\
\hline & $\begin{array}{c}\mathrm{cm}^{2} \operatorname{limb} \\
\mathrm{x} \text {-sectional area }\end{array}$ & $\begin{array}{c}100 \text { blossom } \\
\text { clusters }\end{array}$ & & & & \\
\hline 0 & 5.3 & 47 & 150 & 177 & 8.4 & 21.3 \\
\hline 125 & 6.2 & 58 & 142 & 165 & 6.1 & 21.0 \\
\hline 250 & 8.2 & 76 & 126 & 190 & 4.1 & 20.3 \\
\hline 375 & 9.8 & 101 & 120 & 192 & 3.3 & 16.0 \\
\hline Summer pruning & 5.5 & 60 & 147 & 162 & 10.1 & 14.8 \\
\hline \multicolumn{7}{|l|}{ Significance } \\
\hline BAS 125 & $\mathrm{~L}^{* * * *}$ & $\mathrm{~L}^{* * *}$ & $\mathrm{~L}^{* * *}$ & NS & $\mathrm{Q}^{* * *}$ & $\mathrm{~L}^{*}$ \\
\hline $\begin{array}{l}\text { Summer pruning vs. } \\
\text { control }\end{array}$ & NS & NS & NS & NS & NS & $*$ \\
\hline $\begin{array}{l}\text { Summer pruning vs. } \\
\text { BAS } 125\end{array}$ & $*$ & NS & $* * *$ & NS & $* * *$ & NS \\
\hline
\end{tabular}

$\overline{\mathrm{Ns}, *, * *, * * *}$ Nonsignificant or significant at $P \leq 0.05,0.01$, or 0.001 , respectively; $\mathrm{L}=$ linear, $\mathrm{Q}=$ quadratic.

Table 3. Effects of concentration of BAS 125 and summer pruning on fruit quality of 'McIntosh' apple before and after 20 weeks air storage at $0{ }^{\circ} \mathrm{C}$. Treatments applied 31 May.

\begin{tabular}{|c|c|c|c|c|c|c|c|c|}
\hline \multirow[b]{2}{*}{$\begin{array}{l}\text { BAS } 125 \\
\left(\mathrm{mg} \cdot \mathrm{L}^{-1}\right)\end{array}$} & \multicolumn{5}{|c|}{ Before storage } & \multicolumn{3}{|c|}{ After storage } \\
\hline & $\begin{array}{l}\text { Flesh } \\
\text { firmness } \\
(\mathrm{N})\end{array}$ & $\begin{array}{c}\text { Soluble } \\
\text { solids } \\
(\%)\end{array}$ & $\begin{array}{l}\text { Starch } \\
\text { rating }\end{array}$ & $\begin{array}{l}\text { Red } \\
\text { color } \\
(\%)\end{array}$ & $\begin{array}{c}\text { U.S. Extra } \\
\text { fancy } \\
(\%)\end{array}$ & $\begin{array}{l}\text { Flesh } \\
\text { firmness } \\
(\mathrm{N})\end{array}$ & $\begin{array}{c}\text { Decay } \\
(\%)\end{array}$ & $\begin{array}{r}\text { Scald } \\
(\%)\end{array}$ \\
\hline 0 & 65.6 & 10.6 & 5.6 & 62 & 55 & 50.5 & 22.8 & 3.1 \\
\hline 125 & 67.9 & 10.6 & 5.8 & 67 & 68 & 51.4 & 20.2 & 2.4 \\
\hline 250 & 67.4 & 10.3 & 5.9 & 69 & 72 & 53.7 & 15.8 & 3.1 \\
\hline 375 & 68.3 & 10.2 & 6.1 & 71 & 76 & 52.7 & 8.2 & 5.5 \\
\hline Summer pruning & 66.5 & 10.6 & 5.8 & 70 & 73 & 49.5 & 12.1 & 4.7 \\
\hline Significance & & & & & & & & \\
\hline BAS 125 & $\mathrm{~L}^{*}$ & $\mathrm{~L}^{* * *}$ & $\mathrm{~L}^{*}$ & $\mathrm{~L}^{* * * *}$ & $\mathrm{~L}^{* *}$ & $\mathrm{Q}^{* *}$ & $\mathrm{~L}^{*}$ & $\mathrm{~L}^{*}$ \\
\hline Summer pruning vs. control & NS & NS & NS & $* *$ & $*$ & NS & $*$ & NS \\
\hline Summer pruning vs. BAS 125 & NS & $*$ & NS & NS & NS & $* *$ & NS & NS \\
\hline
\end{tabular}

$\overline{\mathrm{Ns}, *, * *, * * * *}$ Nonsignificant or significant at $P \leq 0.05,0.01$, or 0.001 , respectively.

Table 4. Effects of concentration and time of application of BAS 125 on terminal growth of 'Macoun' apple trees. Trees were treated with NAA $\left(10 \mathrm{mg} \cdot \mathrm{L}^{-1}\right)$ plus carbaryl $\left(900 \mathrm{mg} \cdot \mathrm{L}^{-1}\right)$ at the $10-\mathrm{mm}$ stage on $12 \mathrm{June}$.

\begin{tabular}{|c|c|c|c|c|c|c|c|c|c|c|}
\hline \multirow{2}{*}{$\begin{array}{l}\text { BAS } 125 \\
\left(\mathrm{mg} \cdot \mathrm{L}^{-1}\right)^{2}\end{array}$} & \multirow{2}{*}{$\begin{array}{l}\text { Time of } \\
\text { application }\end{array}$} & \multicolumn{9}{|c|}{ Terminal growth $(\mathrm{cm})$} \\
\hline & & $5 / 27$ & $5 / 27$ & $6 / 16$ & $6 / 24$ & $7 / 1$ & $7 / 15$ & $7 / 29$ & $8 / 12$ & $10 / 30$ \\
\hline 0 & & 4.9 & 13.4 & 17.8 & 22.5 & 28.0 & 31.4 & 32.4 & 32.4 & 35.0 \\
\hline 30 & $5 / 28,6 / 11,6 / 25$ & 5.0 & 12.9 & 15.2 & 16.0 & 17.6 & 18.4 & 19.2 & 19.2 & 20.6 \\
\hline 60 & $5 / 28,6 / 11,6 / 25$ & 4.5 & 12.2 & 13.5 & 15.5 & 16.9 & 17.6 & 18.2 & 16.8 & 19.4 \\
\hline 90 & $5 / 28,6 / 11,6 / 25$ & 5.1 & 12.5 & 14.9 & 16.4 & 17.8 & 17.6 & 18.2 & 19.4 & 19.4 \\
\hline 90,180 & $5 / 28,6 / 25$ & 4.8 & 13.0 & 15.6 & 16.8 & 18.7 & 20.2 & 18.8 & 19.2 & 21.0 \\
\hline 270 & $5 / 28$ & 4.7 & 10.9 & 12.8 & 13.7 & 15.1 & 16.2 & 16.6 & 15.4 & 15.8 \\
\hline \multicolumn{11}{|c|}{ Significance } \\
\hline \multicolumn{2}{|c|}{ BAS 125} & NS & * & $* *$ & $* * *$ & $* * *$ & $* * *$ & $* * *$ & $* * *$ & $* * *$ \\
\hline \multicolumn{2}{|c|}{ BAS 125 concn (T1-4) } & NS & NS & $L^{* *}, Q^{*}$ & $L^{* * *}, Q^{* *}$ & $\mathrm{~L}^{* *}$ & $\mathrm{~L}^{* * *}, \mathrm{Q}^{* *}$ & $\mathrm{~L}^{* * *}, \mathrm{Q}^{* *}$ & $\mathrm{~L}^{* * *}, \mathrm{Q}^{* * * *}$ & $\mathrm{~L}^{* * *}, \mathrm{Q}^{* *}$ \\
\hline \multicolumn{2}{|c|}{ BAS 125 Time of application (T4-6) } & NS & $L^{*}, Q^{*}$ & NS & NS & NS & NS & NS & NS & NS \\
\hline
\end{tabular}

${ }^{2}$ BAS 125 applied initially at PF (5/28) with $0.1 \%$ Regulaid in $1870 \mathrm{~L} \cdot \mathrm{ha}^{-1}(\mathrm{TRV})$. Similar treatments were applied on 11 and 25 June. Ns, ***,***, Nonsignificant at $P \leq 0.001,0.01$, or 0.05 , respectively.

pruning increased both red color and the percentage of fruit graded as U.S. Extra Fancy, confirming previous reports (Autio and Greene, 1990; Lord and Greene, 1982; Marini and Barden, 1982). Treatment with BAS 125 retarded shoot growth, thus also increasing both light penetration and color development comparable to summer pruning. Therefore, the requirement for skilled summer pruning labor might be substantially reduced by using BAS 125 early in the season.

The recommended time of application of foliar-applied growth retardants such as ethephon is when terminal growth is 7 to $12 \mathrm{~mm}$ in length (Greene, 1996). Growth retardation occurs relatively rapidly, resulting in substantial growth retardation by the end of the season. Meaningful growth retardation on BAS 125-treated trees was not apparent for at least 10 to $14 \mathrm{~d}$ after application in both experiments. If BAS 125 application were delayed until shoot growth was 12 to 13 $\mathrm{cm}$, and if growth retardation required an additional $14 \mathrm{~d}$, then twothirds of the total growth for the year would have occurred before the treatment became effective. A better strategy was employed in Expt. 2 , where application was made at PF, when sufficient leaf development had occurred for good foliar absorption; thus growth was slowed earlier and consequently shoot growth for the year was reduced more.

Recommended concentrations for commercial applications of BAS 125 will undoubtedly be low early in the season for two reasons. First, BAS 125 is a growth retardant and application at this time of rapid cell division will undoubtedly reduce fruit size. This was observed in Expt. 1, when treatments were applied as a dilute handgun application, and in Expt. 2 at the highest rate $\left(270 \mathrm{mg} \cdot \mathrm{L}^{-1}\right)$. Secondly, BAS 125 can increase fruit set, as it did in Expt. 1. This could be beneficial, but in most circumstances growers attempt to reduce crop load rather than increase it. Increased fruit set can reduce both fruit size and return bloom, as was observed in Expt. 1.

Thinning recommendations on trees treated with BAS 125 may require modification even if lower rates are used. All trees in Expt. 1 were treated with NAA and carbaryl at the 10-mm stage of fruit development. Final fruit set on control and summer-pruned trees fell into the ideal level of five to six fruit per $\mathrm{cm}$ of limb cross-sectional area (Childers, 1995). Inadequate thinning was experienced when this same thinning spray was applied to trees treated with BAS 125. Fruit set was linear with concentration, suggesting that more aggressive 
thinning treatments would be required, which carry inherently greater risk of excessive thinning or a further reduction in fruit size if higher rates of NAA are used.

Treatment with BAS 125 increased flesh firmness following storage and improved storage life by reducing decay. Calcium plays an important role in determining the storage potential of fruit (Bramlage et al., 1979). The Ca status of fruit may be increased by reducing fruit size, which limits $\mathrm{Ca}$ dilution, or by reducing terminal growth. Actively growing shoots compete with fruit for Ca. Since BAS 125 reduced fruit size, the lower fruit decay in Expt. 1 could have resulted from smaller fruit size, reduced terminal growth, or a combination of the two.

\section{Literature Cited}

Alderman, W.H. and E.C. Auchter. 1916. The apple as affected by varying degrees of dormant and seasonal pruning. West Virginia Expt. Sta. Bul. 158.

Autio, W.R. and D.W. Greene. 1990. Summer pruning affects yield and improves fruit quality of 'McIntosh' apples. J. Amer. Soc. Hort. Sci. 115:356-359.

Autio, W.R. and D.W. Greene. 1994. Effect of growth retardant treatments on apple tree growth, fruit maturation, and fruit abscission. J. Hort. Sci. 69:653-664.

Bramlage, W.J., M. Drake, and J.H. Baker. 1979. Changes in calcium levels in apple cortex tissue shortly before harvest and during postharvest storage. Commun. Soil. Sci. 10:417-426.

Cain, J.C. 1971. Effect of mechanical pruning of apple hedgerows with a slotted saw on light penetration and fruiting. J. Amer. Soc. Hort. Sci. 96:664-667.

Cleland, R.E. 1969. The gibberellins, p. 49-81. In: M. B. Williams (ed.). Physiology of plant growth and development. McGraw Hill, Maidenhead, Berkshire, England.

Childers, N.F., J.R. Morris, and G.S. Sibbett. 1995. Modern fruit science, $10^{\text {th }}$ ed. Horticultural Publ., Gainesville, Fla.

Elfving, P.C. and J.T.A. Proctor. 1986. Long-term effects of paclobutrazol (Cultar) on apple tree shoot growth, cropping, and fruit-leaf relations. Acta Hort. 179:473-480.
Felland, C.M. (Coordinator). 1998. Pennsylvania tree fruit production guide, 1998-1999. Pennsylvania State Univ., University Park.

Forshey, C.G., D.C. Elfving, and R.L. Stebbins. 1992. Training and pruning of apple and pear trees. Amer. Soc. Hort. Sci., Alexandria, Va.

Greene, D.W. 1991. Reduced rates and multiple sprays of paclobutrazol control growth and improve fruit quality of 'Delicious' apples. J. Amer. Soc. Hort. Sci. 116:807-812.

Greene, D.W. 1996. Ethylene-based preharvest growth regulators, p. 149-159. In: K. Maib, P. Andrews, G. Lang, and K. Mullinix (eds.). Tree fruit physiology: Growth and development. Good Fruit Grower, Yakima, Wash.

Greene, D.W. and W.R. Autio. 1994. A review of methods to control vegetative growth of apple trees. The Mountaineer Grower 524:24-32.

Greene, D.W., K. Kaminsky, and J. Sincuk. 1987. An evaluation of stop drop materials in 1986. Proc. Massachusetts Fruit Growers' Assn. 93:74-78.

Heinicke, D.R. 1975. High density apple orchards - planning, training, and pruning. USDA Agr. Hdbk. 458:1-34.

Jones, R.L. and I.D.J. Phillips. 1966. Organs of gibberellin synthesis in lightgrown sunflower plants. Plant Physiol. 41:1381-1386.

Lord, W.J. and D.W. Greene. 1982. Effects of summer pruning on the quality of 'McIntosh' apples. HortScience 17:372-373.

Marini, R.P. and J.A. Barden. 1982. Yield, fruit size, and quality of three apple cultivars as influenced by summer or dormant pruning. J. Amer. Soc. Hort. Sci. 107:474-479.

Pearson, A.H. 1895. Pruning fruit trees. J. Royal Hort. Sci. 19:270-279.

Priest, K.L. and E.C. Lougheed. 1988. Evaluating maturity of McIntosh and Red Delicious apples. Ontario Min. of Agr. and Food Factsheet No. 88117.

Rademacher, W. 1991. Inhibitors of gibberellin biosynthesis: Applications in agriculture and horticulture, p. 296-310. In: N. Tahahaski, B.O. Phinney, and J. MacMillan (eds.). Springer-Verlag, New York.

Rademacher, W., K.E. Temple-Smith, D.L. Griggs, and P. Hedden. 1992. The mode of action of acylcyclohexanediones-A new type of growth regulant, p. 571-577. In: C.M. Karssen, L.C. van Loon, and D. Vreulgdenhil (eds.) Progress in plant growth regulation. Kluwer Academic, Dordrecht, The Netherlands.

Schupp, J.R. and D.C. Ferree. 1988. Effects of root pruning at four levels of severity on growth and yield of 'Melrose'/M.26 apple trees. J. Amer. Soc. Hort. Sci. 113:194-198. 